\title{
Identification of Novel Physiological Races of Phytophthora capsici Causing Foliar Blight Using the New Mexico Recombinant Inbred Pepper Lines Set as a Host Differential
}

\author{
Ariadna Monroy-Barbosa ${ }^{1}$ and Paul W. Bosland ${ }^{2,3}$ \\ Department of Plant and Environmental Sciences, New Mexico State University, Las Cruces, \\ NM 88003
}

\begin{abstract}
Additional Index words. Capsicum, chile pepper, disease resistance, pepper, race-specific resistance, RILs
Abstract. Phytophthora foliar blight caused by Phytophthora capsici is a serious limitation to pepper (Capsicum annuиm) production worldwide. Knowledge of the physiological race composition of isolates causing phytophthora foliar blight is necessary for success in breeding for disease resistance. The New Mexico recombinant inbred lines (NMRILs) effectively differentiated isolates from different geographical locations (i.e., Turkey, The Netherlands, Argentina, and two states in the United States) into 12 physiological races of $P$. capsici causing phytophthora foliar blight. This research demonstrates the use of the NMRILs to identify $\boldsymbol{P}$. capsici foliar blight races and the importance of identifying the physiological races occurring in specific regions where a $C$. annuum cultivar will be grown. Knowing the physiological race(s) in a region will provide valuable information to formulate breeding strategies to deploy durable foliar blight resistance.
\end{abstract}

Phytophthora capsici, the causal agent of phytophthora blight, continues to threaten the livelihood of growers and the future of pepper production in the United States and globally. Growers and processors of pepper rank $P$. capsici as a top threat to production and long-term viability of pepper crops (Foster and Hausbeck, 2010; Skaggs et al., 2000). Several disease syndromes are caused by $P$. capsici on peppers, including root rot, stem blight, foliar blight, and fruit rot (Bosland and Lindsey, 1991; Sy et al., 2005). The foliar blight syndrome is a serious problem in areas with high humidity (Gevens et al., 2008) or during the fall rainy period in other regions (Alcantara and Bosland, 1994; Barksdale et al., 1983). Because the pathogen presents different physiological races for the syndromes root rot and foliar blight, breeding P. capsiciresistant cultivars has been an arduous task (Glosier et al., 2007; Oelke et al., 2003; Sy et al., 2008). P. capsici requires two mating types (A1 and A2) to complete the sexual stage; when both mating types are present, the probability of genetic recombination increases, leading to the formation of new physiological races (Erwin and Ribeiro, 1996; Polach and Webster, 1972). Moreover, the presence of both mating types has been reported in the United States (Fernandez-Pavia et al., 2004; Parra and Ristaino, 2001). Therefore, it is paramount that breeding programs know the physiological race structure in the locale where the cultivar will be grown to provide durable phytophthora foliar blight resistance for the grower.

One of the most cost-effective means to manage diseases, including phytophthora foliar blight, is through host resistance. Resistant plants become an efficient, cost-effective, competitive, and non-polluting method in the control of a pathogen. Resistance

Received for publication 3 Jan. 2011. Accepted for publication 25 Mar. 2011. A contribution of the New Mexico Agr. Expt. Sta., New Mexico State Univ., Las Cruces, NM.

${ }^{1}$ Graduate Research Assistant.

${ }^{2}$ Regents Professor

${ }^{3}$ Corresponding author. E-mail: pbosland@nmsu.edu. to plant pathogens with a single gene-mediated reaction blocks or reduces infection, colonization, and reproduction of the pathogen. Thus, single gene-mediated resistance is frequently favored by plant breeders as a result of its large effect and ease of selection in breeding programs (Acquaah, 2007).

However, this vertical resistance requires characterization of the different physiological races within the pathogen. A physiological race of a pathogen is defined as the pathogen genotypes that are virulent to the same host (Stakman, 1919). Physiological races can be characterized by their response to a specific set of host cultivars (Caten, 1987). Physiological races of a pathogen are categorized based on the gene-for-gene theory, in which different avirulence genes $(A v r)$ in the pathogen are recognized by specific resistant genes $(R)$ in the host (Flor, 1955). The specificity of this interaction identifies the different physiological races of the pathogen by their qualitative disease reaction (Leonard, 2005). The first host differential was reported by Barrus (1911), in which several races of anthracnose (Colletotrichum lindemuthianum) were identified using different bean (Phaseolus vulgaris) cultivars. Since that report, a range of host differentials has been used to successfully characterize physiological races in other crops (Andrie et al., 2006; Cho and Goodman, 1979; Dutta et al., 1960; Irish et al., 2007; Poswal, 1988). Currently, in soybean (Glycine max), more than 50 physiological races of Phytophthora sojae have been reported using a host differential (Bhattacharyya et al., 2005). In C. annuum, nine physiological races of $P$. capsici causing the root rot syndrome and four physiological races of $P$. capsici causing the foliar blight syndrome were identified by Oelke et al. (2003) using a set of different cultivars of Capsicum as the host differential. Glosier et al. (2007) identified 14 physiological races for the phytophthora root rot syndrome using a set of different $C$. апnиum cultivars.

A host differential based on recombinant inbred lines provides the advantage of combining the maximum genetic variability within the population with homozygous genotypes that can be replicated permanently without risk of segregation (Bosland, 2008). Using the NMRIL population, 11 novel physiological 
races of $P$. capsici causing root rot syndrome were successfully identified (Sy et al., 2008). If NMRILs could also be used as a host differential to characterize physiological races of $P$. capsici causing the foliar blight syndrome, this could establish a stable and efficient host differential for foliar blight race designation that could be useful to plant breeders in deploying durable phytophthora foliar blight-resistant cultivars. The objective of this study was to test the feasibility of characterizing several different isolates of $P$. capsici into physiological races using the NMRILs as a host differential.

\section{Materials and Methods}

Plant material. In this study, a subset of 26 NMRILs from the 72 C. annuum (NMRIL F $2: 8$ ) population was used (Sy et al., 2008). The subset of 26 lines was selected based on the results reported by Sy et al. (2008). The NMRILs are part of the New Mexico chile pepper breeding program germplasm collection and are available through New Mexico State University. For the resistant controls, Criollo de Morelos-334 (CM-334), a landrace from Mexico with broad $P$. capsici resistance, and one of the parents in the development of the NMRILs were used. For the susceptible control, a susceptible commercial bell pepper cultivar (Camelot; Seminis Vegetable Seeds, St. Louis, MO) was used.

In a greenhouse located at the New Mexico State University's Fabian Garcia Science Center (Las Cruces), seeds of each NMRIL and the controls were sown in 96-celled plastic trays $(4 \times 3 \times 5.5 \mathrm{~cm} ;$ T.O. Plastics, Clearwater, MN). Trays were filled with a commercial peatmoss-vermiculite mixture (Rediearth Plug \& Seedling Mix; Sun Gro Horticulture, Bellevue, WA). The trays were watered twice per day for 2 weeks. Seedlings were transplanted into 18 -celled plastic trays $(7.94 \times$ $7.94 \times 5.72 \mathrm{~cm}$; T.O. Plastics) filled with the same peatmossvermiculite mixture to obtain plants with fully expanded leaves. Plants were fertilized with a $14 \mathrm{~N}-6.2 \mathrm{P}-11.6 \mathrm{~K}$ slow-release fertilizer (Scotts, Marysville, $\mathrm{OH}$ ) and were maintained for 2 weeks more until they reached the four- to six-true leaf stage.

PHYTOPHTHORA CAPSICI ISOLATES AND INOCULUM PREPARATION. A total of $12 P$. capsici isolates from two states in the United States and three other countries were used in this study (Table 1). The inoculum preparation followed the procedures of MonroyBarbosa and Bosland (2010). The isolates were maintained in darkness separately on water agar medium [2\% agar (Bacto agar; Benton, Dickinson and Co., Sparks, MD)] at $24{ }^{\circ} \mathrm{C}$ in parafilmed petri plates $(100 \times 15 \mathrm{~mm})$. For inoculation, a 0.5 -cm-diameter plug was cut from the water agar medium and transferred to V8 juice agar medium [Bacto agar $(2 \%), \mathrm{CaCO}_{3}(0.3 \%)$, clarified V8 juice $(12 \%)$, distilled water $(85.7 \%)]$. The cultures were maintained in an incubator at $28^{\circ} \mathrm{C}$ for $8 \mathrm{~d}$ until sporangia were profuse. Then, the V8 juice agar was cut into $2 \times 2-\mathrm{cm}$ pieces and transferred to $150 \times 15-\mathrm{mm}$ petri plates filled with $30 \mathrm{~mL}$ distilled water. The plates were maintained in an incubator for $2 \mathrm{~d}$ at $28^{\circ} \mathrm{C}$. To promote zoospore release, the water plates were incubated at $10{ }^{\circ} \mathrm{C}$ for an additional $1 \mathrm{~h}$ and placed back into a $28{ }^{\circ} \mathrm{C}$ incubator for $1 \mathrm{~h}$. The zoospores were collected and counted using a hemacytometer. The final inoculum suspension was adjusted to 40,000 zoospores/mL (Oelke et al., 2003; Sy et al., 2005).

Mating type Determination. Phytophthora capsici has two mating types, A1 and A2. Mating types for some of the isolates used in this study were determined by Sy et al. (2008). To determine the mating type of the unknown isolates, each isolate was individually paired with a known A1 and A2 mating type isolate on V8 juice agar plates. After 1 week, the agar plates with the two isolates were examined using a microscope with $20 \times$ magnification for oospore formation. An indicator of opposite mating types is the formation of oospores.

SCREENING METHOD. The plants were inoculated following the multiple-race disease screening technique described by MonroyBarbosa and Bosland (2010). Three mature leaves were randomly selected per single plant. A $0.5-\mathrm{cm}$-diameter paper disc cut from seed germination paper (Nasco, Modesto, CA) was placed on the surface of each leaf, and $50 \mu \mathrm{L}$ of inoculum was applied to the paper disc. The paper disc prevents the runoff of the inoculum toward the stems and the roots and focuses the contact of the inoculum suspension to the leaf surface in a specific area during the screening time. Each of the three mature leaves was inoculated with a single and a different isolate from the other leaves inoculated in the same plant. The plants were placed into a mist chamber (Alcantara and Bosland, 1994) with relative humidity maintained at $70 \%$ and an air temperature of $28{ }^{\circ} \mathrm{C}$. Resistant and susceptible control plants were inoculated with the same technique. Also, an extra leaf was inoculated with distilled water as a control of the method.

Table 1. List of Phytophthora capsici isolates used for phytophthora foliar blight screening with their designation, mating type, acquisition date, origin, and provider of the isolates.

\begin{tabular}{lccl}
\hline Isolate designation $^{\mathrm{z}}$ & Mating type $^{\mathrm{y}}$ & Acquisition yr & Source $^{\mathrm{x}}$ \\
\hline PWB-24 & A2 & 1988 & P. Bosland, New Mexico State University, Las Cruces, NM \\
PWB-54 (Hallock) & A2 & 1999 & S. Johnston, Rutgers University, New Brunswick, NJ \\
PWB-57 (Probasco) & A1 & 1999 & S. Johnston, Rutgers University, New Brunswick, NJ \\
PWB-66 (Pc6022) & A1 & 2000 & R. Creamer, New Mexico State University, Las Cruces, NM \\
PWB-73(DEM-1) & A1 & 2000 & G. Cakir, Akdeniz University, Konyaalt1, Turkey \\
PWB-80 (PA-14-9 ag) & A1 & 2000 & G. Stoorvogel, De Ruiter Seed, Bergschenhoek, The Netherlands \\
PWB-85 (6021) & A2 & 2004 & S. Sanogo, New Mexico State University, Las Cruces, NM \\
PWB-86 (6022) & A1 & 1988 & S. Sanogo, New Mexico State University, Las Cruces, NM \\
PWB-89 (6029) & A1 & 2083 & S. Sanogo, New Mexico State University, Las Cruces, NM \\
PWB-101 (6534) & A1 & 2006 & S. Sanogo, New Mexico State University, Las Cruces, NM \\
PWB-107 (PILC-4) & A1 & C. Galmarini, INTA, Lujan de Cuyo, Argentina \\
PWB-110 (PILC-19) & A1 & C. Galmarini, INTA, Lujan de Cuyo, Argentina \\
\hline
\end{tabular}

${ }^{\mathrm{z} P W B}=$ P.W. Bosland, P. capsici collection (New Mexico State University, Las Cruces, NM).

${ }^{\mathrm{y}}$ Isolates of $P$. capsici either mating type A1 or A2.

${ }^{\mathrm{x}} \mathrm{INTA}=$ Instituto Nacional de Tecnologia Agropeuaria. 
Scoring. The plants were rated with the following disease assessment scale: $0=$ no symptoms, $1=$ small lesion under the paper disc area (small, dry spots, with defined borders; lesion associated with hypersensitive response), 2 = dark green, watersoaked lesion wider than the paper disc area surrounded by pale yellow undefined borders, $3=15 \%$ to $49 \%$ of leaf area is wilted (scalded or necrotic), $4=50 \%$ or more of the leaf is wilted, and $5=100 \%$ of the leaf is necrotic or the leaf had abscised from the plant. As described by Monroy-Barbosa and Bosland (2010), each leaf displays an individual phenotypic reaction toward the specific isolate. Plants were considered resistant when the leaf scored 0 and 1, whereas leaves scoring 2 through 5 were considered susceptible phenotypes. According to this methodology, tolerance levels are not an accurate strategy to select for resistant material. Plants scored 2 through 5 progressively succumb to the disease, and they do not reach the fruiting stage. Based on the MonroyBarbosa and Bosland (2010) technique, the first foliar blight symptoms are observed $2 \mathrm{~d}$ after inoculation, and the NMRILs and control plants should be scored once the susceptible control displayed a disease assessment level of 5, normally $3 \mathrm{~d}$ after inoculation.

Experimental DeSign. A single leaf was considered the experimental unit. A completely randomized design was used. For each replication, a total of 24 leaves of each NMRIL was screened using 24 plants in each replication. The experiment was repeated three times.

Statistical analysis. Each plant was scored using the disease scale described previously. Levels 0 and 1 were classified as resistant and those scored 2, 3, 4, and 5 were classified as susceptible. The total number of plants in the respective category was tested against the resistant and the susceptible control using the chi-square test of homogeneity $(P>0.05)$. If a given NMRIL had a significant difference from the susceptible control and no significant difference from the resistant control, it was considered resistant. Conversely, a NMRIL was considered susceptible when the homogeneity test had a significant difference from the resistant control and no significant difference from the susceptible control. NMRILs that did not fit into any of the categories were considered heterozygous $(\mathrm{H})$. Data were analyzed using SAS (Version 9.2; SAS Institute, Cary, NC). Also, a chi-square test of homogeneity was performed to test for the ability to pool the data among the replications for each NMRIL-isolate combination $(P>0.05)$ (data not shown). The test of homogeneity allowed for pooling of the data.

\section{Results}

The distilled water control did not present disease symptoms in any of the replications. The resistant control, CM-334, manifested a foliar blight-resistant phenotype (scored 0) against all $P$. capsici isolates tested. The susceptible control displayed a susceptible reaction (scored 5) against all the isolates (Table 2). Based on the chi-square test (data not shown), the 26 inoculated NMRILs were identified either as resistant (R) or susceptible (S) to the different isolates (Table 2). The 12 isolates varied in virulence (extent of the disease based on the number of NMRILs infected). In this study, a $P$. capsici race-specific resistance interaction was observed on $C$. annuum (Table 2). Based on the total number of susceptible NMRILs, the most virulent isolate was PWB-85 from New Mexico with all of the 26 NMRILs exhibiting susceptibility. The least virulent isolate was PWB-54 from New Jersey with only one NMRIL exhibiting susceptibility.
Table 2. Phenotypic foliar blight response of 26 Capsicum annuum New Mexico recombinant inbred lines (NMRILs) and resistant and susceptible pepper controls when challenged by 12 isolates of Phytophthora capsici.

\begin{tabular}{|c|c|c|c|c|c|c|c|c|c|c|c|c|}
\hline \multirow[b]{2}{*}{ Accession } & \multicolumn{12}{|c|}{ PWB isolates of Phytophthora capsici ${ }^{\mathrm{z}}$} \\
\hline & 85 & 80 & 86 & 24 & 110 & 73 & 107 & 101 & 66 & 89 & 57 & 54 \\
\hline $\mathrm{CM}-334^{\mathrm{y}}$ & $\mathrm{R}^{\mathrm{x}}$ & $\mathrm{R}$ & $\mathrm{R}$ & $\mathrm{R}$ & $\mathrm{R}$ & $\mathrm{R}$ & $\mathrm{R}$ & $\mathrm{R}$ & $\mathrm{R}$ & $\mathrm{R}$ & $\mathrm{R}$ & $\mathrm{R}$ \\
\hline NMRIL-B $^{w}$ & $\mathrm{~S}^{\mathrm{v}}$ & $\mathrm{R}$ & $\mathrm{R}$ & $\mathrm{R}$ & $\mathrm{R}$ & $\mathrm{R}$ & $\mathrm{R}$ & $\mathrm{R}$ & $\mathrm{R}$ & $\mathrm{R}$ & $\mathrm{R}$ & $\mathrm{R}$ \\
\hline NMRIL-A & $\mathrm{S}$ & $\mathrm{S}$ & $\mathrm{R}$ & $\mathrm{R}$ & $\mathrm{R}$ & $\mathrm{R}$ & $\mathrm{R}$ & $\mathrm{R}$ & $\mathrm{R}$ & $\mathrm{R}$ & $\mathrm{R}$ & $\mathrm{R}$ \\
\hline NMRIL-C & $\mathrm{S}$ & $\mathrm{S}$ & $\mathrm{R}$ & $\mathrm{R}$ & $\mathrm{S}$ & $\mathrm{R}$ & $\mathrm{R}$ & $\mathrm{R}$ & $\mathrm{R}$ & $\mathrm{R}$ & $\mathrm{R}$ & $\mathrm{R}$ \\
\hline IMRIL-F & $\mathrm{S}$ & $\mathrm{R}$ & $\mathrm{R}$ & $\mathrm{R}$ & $\mathrm{R}$ & $\mathrm{R}$ & $\mathrm{R}$ & $\mathrm{R}$ & $\mathrm{R}$ & $\mathrm{R}$ & $\mathrm{R}$ & $\mathrm{R}$ \\
\hline NMRIL-P & $\mathrm{S}$ & S & $\mathrm{S}$ & $\mathrm{R}$ & $\mathrm{S}$ & $\mathrm{R}$ & $\mathrm{R}$ & $\mathrm{R}$ & $\mathrm{R}$ & $\mathrm{R}$ & $\mathrm{R}$ & $\mathrm{R}$ \\
\hline JMRIL-Q & $\mathrm{S}$ & $\mathrm{S}$ & $\mathrm{R}$ & $\mathrm{R}$ & $\mathrm{S}$ & $\mathrm{R}$ & $\mathrm{R}$ & $\mathrm{R}$ & $\mathrm{R}$ & $\mathrm{R}$ & $\mathrm{R}$ & $\mathrm{R}$ \\
\hline NMRIL-V & $\mathrm{S}$ & S & $\mathrm{R}$ & $\mathrm{R}$ & $\mathrm{S}$ & $\mathrm{R}$ & $\mathrm{R}$ & $\mathrm{R}$ & $\mathrm{R}$ & $\mathrm{R}$ & $\mathrm{R}$ & $\mathrm{R}$ \\
\hline NMRIL-I & $\mathrm{S}$ & $\mathrm{S}$ & $\mathrm{R}$ & $\mathrm{R}$ & $\mathrm{S}$ & $\mathrm{R}$ & $\mathrm{R}$ & $\mathrm{R}$ & $\mathrm{R}$ & $\mathrm{R}$ & $\mathrm{S}$ & $\mathrm{R}$ \\
\hline NMRIL-J & $\mathrm{S}$ & $\mathrm{S}$ & $\mathrm{R}$ & $\mathrm{S}$ & $\mathrm{S}$ & $\mathrm{R}$ & $\mathrm{R}$ & $\mathrm{R}$ & $\mathrm{R}$ & $\mathrm{R}$ & $\mathrm{R}$ & $\mathrm{R}$ \\
\hline NMRIL-K & $\mathrm{S}$ & $\mathrm{S}$ & $\mathrm{R}$ & $\mathrm{S}$ & $\mathrm{R}$ & $\mathrm{R}$ & $\mathrm{R}$ & $\mathrm{R}$ & $\mathrm{R}$ & $\mathrm{R}$ & $\mathrm{R}$ & $\mathrm{R}$ \\
\hline NMRIL-G & $\mathrm{S}$ & $\mathrm{S}$ & $\mathrm{S}$ & $\mathrm{S}$ & $\mathrm{S}$ & $\mathrm{R}$ & $\mathrm{R}$ & $\mathrm{R}$ & $\mathrm{R}$ & $\mathrm{R}$ & $\mathrm{R}$ & $\mathrm{R}$ \\
\hline NMRIL-L & $\mathrm{S}$ & $\mathrm{S}$ & $\mathrm{S}$ & $\mathrm{R}$ & $\mathrm{S}$ & $\mathrm{R}$ & $\mathrm{R}$ & $\mathrm{R}$ & $\mathrm{R}$ & $\mathrm{R}$ & $\mathrm{R}$ & $\mathrm{R}$ \\
\hline NMRIL-O & $\mathrm{S}$ & $\mathrm{S}$ & $\mathrm{S}$ & $\mathrm{S}$ & $\mathrm{R}$ & $\mathrm{S}$ & $\mathrm{R}$ & $\mathrm{R}$ & $\mathrm{R}$ & $\mathrm{R}$ & $\mathrm{R}$ & $\mathrm{R}$ \\
\hline NMRIL-T & $\mathrm{S}$ & $\mathrm{S}$ & $\mathrm{S}$ & $\mathrm{S}$ & $\mathrm{S}$ & $\mathrm{R}$ & $\mathrm{R}$ & $\mathrm{R}$ & $\mathrm{R}$ & $\mathrm{R}$ & $\mathrm{R}$ & $\mathrm{R}$ \\
\hline NMRIL-X & $\mathrm{S}$ & $\mathrm{S}$ & $\mathrm{S}$ & $\mathrm{R}$ & $\mathrm{S}$ & $\mathrm{R}$ & $\mathrm{R}$ & $\mathrm{R}$ & $\mathrm{R}$ & $\mathrm{R}$ & $\mathrm{R}$ & $\mathrm{R}$ \\
\hline NMRIL-H & $\mathrm{S}$ & $\mathrm{S}$ & $\mathrm{S}$ & $\mathrm{S}$ & $\mathrm{S}$ & $\mathrm{R}$ & $\mathrm{S}$ & $\mathrm{R}$ & $\mathrm{R}$ & $\mathrm{R}$ & $\mathrm{R}$ & $\mathrm{R}$ \\
\hline NMRIL-S & $\mathrm{S}$ & $\mathrm{S}$ & $\mathrm{S}$ & $\mathrm{S}$ & $\mathrm{R}$ & $\mathrm{R}$ & $\mathrm{R}$ & $\mathrm{R}$ & $\mathrm{R}$ & $\mathrm{R}$ & $\mathrm{S}$ & $\mathrm{R}$ \\
\hline NMRIL-N & $\mathrm{S}$ & $\mathrm{S}$ & $\mathrm{S}$ & $\mathrm{S}$ & $\mathrm{S}$ & $\mathrm{R}$ & $\mathrm{R}$ & $\mathrm{R}$ & $\mathrm{R}$ & $\mathrm{R}$ & $\mathrm{R}$ & $\mathrm{R}$ \\
\hline NMRIL-Z & $\mathrm{S}$ & $\mathrm{S}$ & $\mathrm{S}$ & $\mathrm{S}$ & $\mathrm{S}$ & $\mathrm{R}$ & $\mathrm{R}$ & $\mathrm{R}$ & $\mathrm{R}$ & $\mathrm{R}$ & $\mathrm{R}$ & $\mathrm{R}$ \\
\hline NMRIL-AA & $\mathrm{S}$ & $\mathrm{S}$ & $\mathrm{S}$ & $\mathrm{R}$ & $\mathrm{S}$ & $\mathrm{S}$ & $\mathrm{R}$ & $\mathrm{R}$ & $\mathrm{S}$ & $\mathrm{R}$ & $\mathrm{R}$ & $\mathrm{R}$ \\
\hline NMRIL-M & $\mathrm{S}$ & $\mathrm{S}$ & $\mathrm{S}$ & $\mathrm{S}$ & $\mathrm{S}$ & $\mathrm{S}$ & $\mathrm{R}$ & $\mathrm{S}$ & $\mathrm{R}$ & $\mathrm{R}$ & $\mathrm{R}$ & $\mathrm{R}$ \\
\hline NMRIL-AB & $\mathrm{S}$ & $\mathrm{S}$ & $\mathrm{S}$ & $\mathrm{S}$ & $\mathrm{R}$ & $\mathrm{R}$ & $\mathrm{R}$ & $\mathrm{R}$ & $\mathrm{S}$ & $\mathrm{S}$ & $\mathrm{R}$ & $\mathrm{R}$ \\
\hline NMRIL-D & $\mathrm{S}$ & $\mathrm{S}$ & $\mathrm{S}$ & $\mathrm{S}$ & $\mathrm{S}$ & $\mathrm{S}$ & $\mathrm{R}$ & $\mathrm{R}$ & $\mathrm{S}$ & $\mathrm{S}$ & $\mathrm{R}$ & $\mathrm{R}$ \\
\hline NMRIL-E & $\mathrm{S}$ & $\mathrm{S}$ & $\mathrm{S}$ & $\mathrm{S}$ & $\mathrm{S}$ & $\mathrm{S}$ & $\mathrm{S}$ & $\mathrm{R}$ & $\mathrm{R}$ & $\mathrm{R}$ & $\mathrm{R}$ & $\mathrm{R}$ \\
\hline NMRIL-R & $\mathrm{S}$ & $\mathrm{S}$ & $\mathrm{S}$ & $\mathrm{S}$ & $\mathrm{S}$ & $\mathrm{S}$ & $\mathrm{S}$ & $\mathrm{S}$ & $\mathrm{R}$ & $\mathrm{R}$ & $\mathrm{R}$ & $\mathrm{R}$ \\
\hline NMRIL-AC & $\mathrm{S}$ & $\mathrm{S}$ & $\mathrm{S}$ & $\mathrm{S}$ & $\mathrm{S}$ & $\mathrm{S}$ & $\mathrm{S}$ & $\mathrm{S}$ & $\mathrm{R}$ & $\mathrm{R}$ & $\mathrm{R}$ & $\mathrm{S}$ \\
\hline Camelot $^{\mathrm{u}}$ & $\mathrm{S}$ & $\mathrm{S}$ & $\mathrm{S}$ & $\mathrm{S}$ & $\mathrm{S}$ & $\mathrm{S}$ & $\mathrm{S}$ & $\mathrm{S}$ & S & $\mathrm{S}$ & $\mathrm{S}$ & $\mathrm{S}$ \\
\hline
\end{tabular}

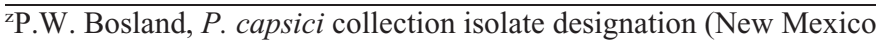
State University, Las Cruces, NM), isolates arranged from most virulent to least virulent.

${ }^{y}$ Resistant control: Criollo de Morelos-334 accession.

${ }^{\mathrm{x}} \mathrm{R}=$ resistant phenotype rated 0 to 1 (no lesions or hypersensitive reaction).

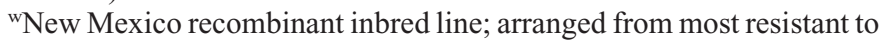
least resistant.

${ }^{\mathrm{v}} \mathrm{S}=$ susceptible phenotype ranging from 2 through 5 (small lesions 1\% or greater, scalded, necrosis, or defoliated leaves).

${ }^{u}$ Susceptible control.

The NMRILs with the highest level of resistance were NMRIL-A, NMRIL-B, NMRIL-C, NMRIL-F, NMRIL-K, NMRIL-L, NMRIL-Q, and NMRIL-V displaying a susceptible phenotype to three or fewer isolates. The most susceptible NMRILs were NMRIL-D, NMRIL-E, NMRIL-M, NMRIL-R, NMRIL-AB, and NMRIL-AC, because they were susceptible to seven or more of the isolates tested. Based on the NMRIL host differential results, 12 physiological races of $P$. capsici causing phytophthora foliar blight were characterized (Table 3).

A new phytophthora foliar blight physiological race designation number was assigned to best match the phytophthora root rot physiological race designation number assigned in the physiological race characterization study of Sy et al. (2008) when the same isolate was used. 
Table 3. Physiological race designation of the 12 Phytophthora capsici isolates based on the Capsicum annuum New Mexico recombinant inbred lines (NMRILs) host differential.

\begin{tabular}{lcccccccccccc}
\hline PWB isolates & $24^{\mathrm{z}}$ & 54 & 57 & 66 & 73 & 80 & 85 & 86 & 89 & 101 & 107 & 110 \\
Race designation & 1 $^{\mathrm{y}}$ & 14 & 15 & 2 & 16 & 3 & 4 & 5 & 17 & 12 & 19 & 20 \\
\hline NMRIL-A $^{\mathrm{x}}$ & $\mathrm{R}^{\mathrm{w}}$ & $\mathrm{R}$ & $\mathrm{R}$ & $\mathrm{R}$ & $\mathrm{R}$ & $\mathrm{S}$ & $\mathrm{S}$ & $\mathrm{R}$ & $\mathrm{R}$ & $\mathrm{R}$ & $\mathrm{R}$ & $\mathrm{R}$ \\
NMRIL-D & $\mathrm{S}$ & $\mathrm{R}$ & $\mathrm{R}$ & $\mathrm{S}$ & $\mathrm{S}$ & $\mathrm{S}$ & $\mathrm{S}$ & $\mathrm{S}$ & $\mathrm{S}$ & $\mathrm{R}$ & $\mathrm{R}$ & $\mathrm{S}$ \\
NMRIL-E & $\mathrm{S}$ & $\mathrm{R}$ & $\mathrm{R}$ & $\mathrm{R}$ & $\mathrm{S}$ & $\mathrm{S}$ & $\mathrm{S}$ & $\mathrm{S}$ & $\mathrm{R}$ & $\mathrm{R}$ & $\mathrm{S}$ & $\mathrm{S}$ \\
NMRIL-F & $\mathrm{R}$ & $\mathrm{R}$ & $\mathrm{R}$ & $\mathrm{R}$ & $\mathrm{R}$ & $\mathrm{R}$ & $\mathrm{S}$ & $\mathrm{R}$ & $\mathrm{R}$ & $\mathrm{R}$ & $\mathrm{R}$ & $\mathrm{R}$ \\
NMRIL-I & $\mathrm{R}$ & $\mathrm{R}$ & $\mathrm{S}$ & $\mathrm{R}$ & $\mathrm{R}$ & $\mathrm{S}$ & $\mathrm{S}$ & $\mathrm{R}$ & $\mathrm{R}$ & $\mathrm{R}$ & $\mathrm{R}$ & $\mathrm{S}$ \\
NMRIL-L & $\mathrm{R}$ & $\mathrm{R}$ & $\mathrm{R}$ & $\mathrm{R}$ & $\mathrm{R}$ & $\mathrm{S}$ & $\mathrm{S}$ & $\mathrm{S}$ & $\mathrm{R}$ & $\mathrm{R}$ & $\mathrm{R}$ & $\mathrm{S}$ \\
NMRIL-M & $\mathrm{S}$ & $\mathrm{R}$ & $\mathrm{R}$ & $\mathrm{R}$ & $\mathrm{S}$ & $\mathrm{S}$ & $\mathrm{S}$ & $\mathrm{S}$ & $\mathrm{R}$ & $\mathrm{S}$ & $\mathrm{R}$ & $\mathrm{S}$ \\
NMRIL-R & $\mathrm{S}$ & $\mathrm{R}$ & $\mathrm{R}$ & $\mathrm{R}$ & $\mathrm{S}$ & $\mathrm{S}$ & $\mathrm{S}$ & $\mathrm{S}$ & $\mathrm{R}$ & $\mathrm{S}$ & $\mathrm{S}$ & $\mathrm{S}$ \\
NMRIL-S & $\mathrm{S}$ & $\mathrm{R}$ & $\mathrm{S}$ & $\mathrm{R}$ & $\mathrm{R}$ & $\mathrm{S}$ & $\mathrm{S}$ & $\mathrm{S}$ & $\mathrm{R}$ & $\mathrm{R}$ & $\mathrm{R}$ & $\mathrm{R}$ \\
NMRIL-V & $\mathrm{R}$ & $\mathrm{R}$ & $\mathrm{R}$ & $\mathrm{R}$ & $\mathrm{R}$ & $\mathrm{S}$ & $\mathrm{S}$ & $\mathrm{R}$ & $\mathrm{R}$ & $\mathrm{R}$ & $\mathrm{R}$ & $\mathrm{S}$ \\
NMRIL-X & $\mathrm{R}$ & $\mathrm{R}$ & $\mathrm{R}$ & $\mathrm{R}$ & $\mathrm{R}$ & $\mathrm{S}$ & $\mathrm{S}$ & $\mathrm{S}$ & $\mathrm{R}$ & $\mathrm{R}$ & $\mathrm{R}$ & $\mathrm{S}$ \\
NMRIL-AA & $\mathrm{R}$ & $\mathrm{R}$ & $\mathrm{R}$ & $\mathrm{S}$ & $\mathrm{S}$ & $\mathrm{S}$ & $\mathrm{S}$ & $\mathrm{S}$ & $\mathrm{R}$ & $\mathrm{R}$ & $\mathrm{R}$ & $\mathrm{S}$ \\
NMRIL-AB & $\mathrm{S}$ & $\mathrm{R}$ & $\mathrm{R}$ & $\mathrm{S}$ & $\mathrm{R}$ & $\mathrm{S}$ & $\mathrm{S}$ & $\mathrm{S}$ & $\mathrm{S}$ & $\mathrm{R}$ & $\mathrm{R}$ & $\mathrm{R}$ \\
NMRIL-AC & $\mathrm{S}$ & $\mathrm{S}$ & $\mathrm{R}$ & $\mathrm{R}$ & $\mathrm{S}$ & $\mathrm{S}$ & $\mathrm{S}$ & $\mathrm{S}$ & $\mathrm{R}$ & $\mathrm{S}$ & $\mathrm{S}$ & $\mathrm{S}$
\end{tabular}

zP.W. Bosland, P. capsici collection (New Mexico State University, Las Cruces, NM), isolates arranged in numerical order.

yPhytophthora foliar blight syndrome new race designation: race designation number matched to the phytophthora root rot race designation number (Sy et al., 2008) of the same isolate.

${ }^{x}$ NMRILs arranged in alphabetical order.

${ }^{\mathrm{w}} \mathrm{R}=$ resistant phenotype rated 0 to 1 (no lesions or lesion $1 \%$ or less on leaves).

${ }^{\mathrm{v}} \mathrm{S}=$ susceptible phenotype ranging from 2 through 5 (small lesions $1 \%$ or greater, scalded, necrosis, or defoliated leaves).

\section{Discussion}

Recombinant inbred lines (RILs) are useful for physiological race characterization and are also a powerful tool for greater resolution in genetic mapping (Broman, 2005). As a result of their ability to carry major genes, RILs have been used in many cases as a host differential. They can result in total resistance to a particular physiological race of a pathogen and are able to recognize physiological races that other differential sets, e.g., cultivars, are not capable of distinguishing (Murphy, 2001; Simon et al., 2004; van Poppel et al., 2009). The NMRILs have proved to be an excellent host differential for characterizing physiological races of $P$. capsici causing phytophthora foliar blight as well as root rot (Sy et al., 2008). Previous studies used a set of cultivars as a differential host set, characterized the isolates PWB-24, PWB-57, and PWB-73 as different physiological races of P. capsici for phytophthora foliar blight (Glosier et al., 2007; Oelke et al., 2003). The NMRIL host differential confirmed these results.

Each $P$. capsici isolate used in this study was a different physiological race, even isolates from the same location (Table 3). For example, the two isolates from Argentina were characterized as two different physiological races, the six isolates from New Mexico were six different physiological races, and the two isolates from New Jersey were two different physiological races. Thus, in breeding for phytophthora foliar blight resistance, one location may require a $C$. annuum cultivar to be resistant to specific physiological races found in that area. Furthermore, there may be several physiological races in one location requiring pyramiding resistance genes to obtain a resistant cultivar. In addition, within each region, plant breeders will need to be aware of the different virulence levels among the physiological races present (Foster and Hausbeck, 2010). For instance, based on the number of NMRILs that were infected, physiological races from New Mexico and The Netherlands were more virulent than physiological races from New Jersey in this study.

A previous study (Monroy-Barbosa and Bosland, 2008) determined the existence of at least four different loci for phytophthora root rot resistance. Because of the gene-for-gene recognition specificity generated when RILs are used as a host differential (van Poppel et al., 2009), at least 12 individual resistance genes and/or alleles for race-specific reactions against phytophthora foliar blight can be found in the C. annuиm genome.

In previous studies, RIL populations were able to recognize pathotype-specific resistant patterns (Cho et al., 2005). This study provides important information on the P. capsici-C. annuum interaction. Moreover, a race-specific resistance interaction was reported in P. capsici causing the phytophthora root rot syndrome (Monroy-Barbosa and Bosland, 2008; Sy et al., 2008). A race-specific resistance interaction in P. capsici causing foliar blight syndrome on $C$. апnиит was observed in this study (Table 2) and in Oelke et al. (2003).

Using the results provided by Sy et al. (2008), the phytophthora foliar blight and root rot disease syndromes were compared (Table 4). When comparing the two disease syndromes, it was observed that a single NMRIL could recognize the $A v r$ genes for both disease syndromes. For example, when the NMRILs were inoculated with the same isolate, some NMRILs were resistant to both disease syndromes, i.e., NMRIL-A, NMRIL-F, and NMRIL-X presented a resistant phenotype to both the root rot and the foliar blight syndromes when inoculated with $P$. capsici race-1. Second, a NMRIL could recognize the $A v r$ gene for one of the disease syndromes (manifest resistance) while exhibiting a susceptible reaction for the other disease syndrome. For example, NMRIL-M and NMRIL-AC recognized an $A v r$ gene when the roots were inoculated with race-12 giving a resistant phenotype but did not recognize any $A v r$ genes when the leaves were inoculated, displaying a susceptible phenotype. Conversely, NMRIL-I, NMRIL-L, and NMRIL-V showed foliar but not root rot resistance to race-1 and race-2. Lastly, NMRILs could be susceptible or resistant to both disease syndromes, i.e., NMRIL-D and NMRIL-AA displayed susceptible phenotype for both disease syndromes when they were inoculated with the $P$. capsici races-1, $-2,-3,-4$, or -5 , whereas NMRIL-A, NMRIL-F, and NMRIL-X were resistant to both disease syndromes. These results demonstrate the importance of the race characterization for the different Phytophthora disease syndromes to develop specific strategies for gene deployment (Fehr, 1991).

Although only 12 isolates of $P$. capsici were used in this study, it was possible to identify nine novel phytophthora foliar blight physiological races different from the four races reported by Oelke et al. (2003) (Table 3). Furthermore, a small set of 14 NMRILs was an efficient host differential to characterize physiological races of $P$. capsici inciting phytophthora foliar blight in $C$. annuum (Table 3). The use of NMRILs to identify novel races in a given location is confirmed by this study.

The identification of novel foliar blight races within a location and among locations provides a better understanding of the physiological race composition to select breeding strategies to manage phytophthora foliar blight disease. For instance, RILs as host differential have been used to track the virulence variability 
Table 4. Comparison of phytophthora root rot and foliar blight syndromes differential reaction using the Capsicum annuum New Mexico recombinant inbred lines (NMRILs).

\begin{tabular}{|c|c|c|c|c|c|c|c|c|c|c|c|c|}
\hline \multirow[b]{4}{*}{ Accessions } & \multicolumn{12}{|c|}{ Phytopththora capsici races } \\
\hline & \multicolumn{2}{|c|}{$1^{z}$} & \multicolumn{2}{|c|}{2} & \multicolumn{2}{|c|}{3} & \multicolumn{2}{|c|}{4} & \multicolumn{2}{|c|}{5} & \multicolumn{2}{|c|}{12} \\
\hline & $r^{\mathrm{y}}$ & $\bar{f}$ & $r$ & $\bar{f}$ & $r$ & $\bar{f}$ & $r$ & $f$ & $r$ & $\bar{f}$ & $r$ & $f$ \\
\hline & \multicolumn{12}{|c|}{ Differential reactions } \\
\hline NMRIL-F $^{x}$ & $\mathrm{R}^{\mathrm{w}}$ & $\mathrm{R}$ & $\mathrm{R}$ & $\mathrm{R}$ & $\mathrm{R}$ & $\mathrm{R}$ & $\mathrm{R}$ & $\mathrm{S}^{\mathrm{v}}$ & $\mathrm{R}$ & $\mathrm{R}$ & $\mathrm{R}$ & $\mathrm{R}$ \\
\hline NMRIL-A & $\mathrm{R}$ & $\mathrm{R}$ & $\mathrm{R}$ & $\mathrm{R}$ & $\mathrm{S}$ & $\mathrm{S}$ & $\mathrm{R}$ & $\mathrm{S}$ & $\mathrm{R}$ & $\mathrm{R}$ & $\mathrm{S}$ & $\mathrm{R}$ \\
\hline NMRIL-X & $\mathrm{R}$ & $\mathrm{R}$ & $\mathrm{R}$ & $\mathrm{R}$ & $\mathrm{R}$ & $\mathrm{S}$ & $\mathrm{S}$ & $\mathrm{S}$ & $\mathrm{R}$ & $\mathrm{S}$ & $\mathrm{S}$ & $\mathrm{R}$ \\
\hline NMRIL-I & $\mathrm{S}$ & $\mathrm{R}$ & $\mathrm{S}$ & $\mathrm{R}$ & $\mathrm{S}$ & $\mathrm{S}$ & S & $\mathrm{S}$ & S & $\mathrm{R}$ & $\mathrm{R}$ & $\mathrm{R}$ \\
\hline NMRIL-V & $\mathrm{S}$ & $\mathrm{R}$ & $\mathrm{S}$ & $\mathrm{R}$ & $\mathrm{S}$ & $\mathrm{S}$ & $\mathrm{S}$ & $\mathrm{S}$ & $\mathrm{S}$ & $\mathrm{R}$ & $\mathrm{R}$ & $\mathrm{R}$ \\
\hline NMRIL-L & $\mathrm{S}$ & $\mathrm{R}$ & $\mathrm{S}$ & $\mathrm{R}$ & $\mathrm{S}$ & $\mathrm{S}$ & S & $\mathrm{S}$ & $\mathrm{S}$ & $\mathrm{S}$ & $\mathrm{R}$ & $\mathrm{R}$ \\
\hline NMRIL-E & $\mathrm{S}$ & $\mathrm{S}$ & $\mathrm{S}$ & $\mathrm{R}$ & $\mathrm{S}$ & $\mathrm{S}$ & $\mathrm{S}$ & $\mathrm{S}$ & $\mathrm{S}$ & $\mathrm{S}$ & $\mathrm{R}$ & $\mathrm{R}$ \\
\hline NMRIL-R & $\mathrm{S}$ & $\mathrm{S}$ & $\mathrm{S}$ & $\mathrm{R}$ & $\mathrm{S}$ & $\mathrm{S}$ & $\mathrm{S}$ & $\mathrm{S}$ & $\mathrm{R}$ & $\mathrm{S}$ & $\mathrm{R}$ & $\mathrm{S}$ \\
\hline NMRIL-S & $\mathrm{S}$ & $\mathrm{S}$ & $\mathrm{S}$ & $\mathrm{R}$ & $\mathrm{S}$ & $\mathrm{S}$ & $\mathrm{S}$ & $\mathrm{S}$ & $\mathrm{S}$ & $\mathrm{S}$ & $\mathrm{R}$ & $\mathrm{R}$ \\
\hline NMRIL-AA & $\mathrm{S}$ & $\mathrm{R}$ & $\mathrm{S}$ & $\mathrm{S}$ & $\mathrm{S}$ & $\mathrm{S}$ & $\mathrm{S}$ & $\mathrm{S}$ & $\mathrm{S}$ & $\mathrm{S}$ & $\mathrm{R}$ & $\mathrm{R}$ \\
\hline NMRIL-M & $\mathrm{S}$ & $\mathrm{S}$ & $\mathrm{S}$ & $\mathrm{R}$ & $\mathrm{S}$ & $\mathrm{S}$ & $\mathrm{S}$ & $\mathrm{S}$ & $\mathrm{S}$ & $\mathrm{S}$ & $\mathrm{R}$ & $\mathrm{S}$ \\
\hline NMRIL-AC & $\mathrm{S}$ & $\mathrm{S}$ & $\mathrm{S}$ & $\mathrm{R}$ & $\mathrm{S}$ & $\mathrm{S}$ & S & $\mathrm{S}$ & $\mathrm{S}$ & $\mathrm{S}$ & $\mathrm{R}$ & $\mathrm{S}$ \\
\hline NMRIL-D & $\mathrm{S}$ & $\mathrm{S}$ & $\mathrm{S}$ & $\mathrm{S}$ & $\mathrm{S}$ & $\mathrm{S}$ & S & $\mathrm{S}$ & S & $\mathrm{S}$ & $\mathrm{S}$ & $\mathrm{R}$ \\
\hline NMRIL-AB & $\mathrm{S}$ & $\mathrm{S}$ & $\mathrm{S}$ & $\mathrm{S}$ & $\mathrm{S}$ & $\mathrm{S}$ & $\mathrm{S}$ & $\mathrm{S}$ & $\mathrm{S}$ & $\mathrm{S}$ & $\mathrm{S}$ & $\mathrm{R}$ \\
\hline
\end{tabular}

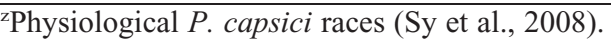

y Phytophthora root rot syndrome $(r)$, phytophthora foliar blight syndrome $(f)$.

${ }^{x}$ NMRILs arranged from most resistant to least resistant.

${ }^{\mathrm{w}} \mathrm{R}=$ resistant phenotype.

${ }^{\mathrm{v}} \mathrm{S}=$ susceptible phenotype.

in Phytophthora infestans populations and to breed cultivars that are resistant to different physiological races of the pathogen (van Poppel et al., 2009). Deployment of $P$. capsici resistance genes could be addressed by pyramiding combinations of race-specific $R$ genes against $P$. capsici isolates for specific geographic regions (Foster and Hausbeck, 2010; Glosier et al., 2007) instead of searching for a universal resistant cultivar.

\section{Literature Cited}

Acquaah, G. 2007. Principles of plant genetics and breeding. 1st Ed. Blackwell Publishing, Malsen, MA.

Alcantara, T.P. and P.W. Bosland. 1994. An inexpensive disease screening technique for foliar blight of chile pepper seedlings. HortScience 29:1182-1183.

Andrie, R.M., I. Pandelova, and L.M. Ciunffetti. 2006. A combination of phenotypic and genotypic characterization strengthens Pyrenophora tritici-repentis race identification. Phytopathology 97:694701.

Barksdale, T.H., G.C. Papavizas, and S.A. Johnston. 1983. Resistance to foliar blight and crown rot of pepper caused by Phytophthora capsici. Plant Dis. 68:506-509.

Barrus, M.P. 1911. Variation on varieties of bean in their susceptibility to anthracnose. Phytopathology 1:190-195.

Bhattacharyya, M.K., N.N. Narayanan, H. Gao, D.K. Santra, S.S. Salimath, T. Kasuga, Y. Liu, B. Espinosa, L. Ellison, L. Marek, R. Shoemaker, M. Gijzen, and R.I. Buzzell. 2005. Identification of a large cluster of coiled coil-nucleotide binding site-leucine rich repeat-type genes from the Rpsl region containing Phytophthora resistance genes in soybean. Theor. Appl. Genet. 111:75-86.

Bosland, P.W. 2008. Think global, breed local: Specificity and complexity of Phytophthora capsici. Proc. 19th Intl. Pepper Conf. 19:14-15.

Bosland, P.W. and D.L. Lindsey. 1991. A seedling screen for phytophthora root rot of pepper, Capsicum annuum. Plant Dis. 75: 1048-1050.
Broman, K.W. 2005. The genome of recombinant inbred lines. Genetics 169:1133-1146.

Caten, C.E. 1987. Concept of race in plant pathology, p. 21-37. In: Wolfe, M.S. and C.E. Caten (eds.). Populations of plant pathogens: Their dynamics and genetics. Blackwell, Oxford, UK.

Cho, E.K. and R.M. Goodman. 1979. Strains of soybean mosaic virus: Classification based on virulence in resistant soybean cultivars. Phytopathology 69:467-470.

Cho, S., W. Chen, and F.J. Muehlbauer. 2005. Constitutive expression of the flavanone 3-hydroxylase gene related to pathotype-specific ascochyta blight resistance in Cicer arietinum L. Physiol. Mol. Plant Pathol. 67:100-107.

Dutta, S.K., C.V. Hall, and E.G. Heyne. 1960. Observations on the physiological races of Colletrotrichum lagenarium. Bot. Gaz. 121:163-166.

Erwin, D.C. and O.K. Ribeiro. 1996. Phytophthora disease worldwide. Amer. Phytopathol. Soc., St. Paul, MN.

Fehr, W.R. 1991. Principles of cultivar development: Theory and technique. Macmillan, Ames, IA.

Fernandez-Pavia, S., C.L. Biles, M. Waugh, K. Onsurez-Waugh, G. Rodriguez-Alvarado, and C.L. Liddell. 2004. Characterization of southern New Mexico Phytophthora capsici Leon. isolates from pepper (Capsicum annuum L.). Rev. Mex. Fitopatol. 22:8289.

Flor, H.H. 1955. Host-parasite interaction in flax rust-its genetic and other implications. Phytopathology 45:680-685.

Foster, J.M. and M.K. Hausbeck. 2010. Resistance of pepper to phytophthora crown, root, and fruit rot is affected by isolate virulence. Plant Dis. 94:24-30.

Gevens, A.J., P.D. Roberts, R.J. McGovern, and T.A. Kucharek. 2008. Vegetable diseases caused by Phytophthora capsici in Florida. 2 Feb. 2011. <http://edis.ifas.ufl.edu/vh045/>.

Glosier, B.R., E.A. Ogundiwin, G.S. Sidhu, D.R. Sischo, and J.P. Prince. 2007. A differential series of pepper (Capsicum annuum) lines delineates fourteen physiological races of Phytophthora capsici. Euphytica 162:23-30.

Irish, B.M., J.C. Correll, S.T. Koike, and T.E. Morelock. 2007. Three new races of spinach downy mildew pathogen identified by a modified set of spinach differentials. Plant Dis. 91:13921396.

Leonard, K.J. 2005. Development of differential varieties-A review. 10 Feb. 2011. <http://www.ars.usda.gov/Main/docs.htm?docid= $10348 />$.

Monroy-Barbosa, A. and P.W. Bosland. 2008. Genetic analysis of phytophthora root rot race-specific resistance in chile pepper. J. Amer. Soc. Hort. Sci. 133:825-829.

Monroy-Barbosa, A. and P.W. Bosland. 2010. A rapid technique for multiple-race disease screening of phytophthora foliar blight on single Capsicum annuum L. plants. HortScience 45:1563-1566.

Murphy, A. 2001. What are the NRBK selections? Potato Gene Resources Nwsl. 8:1-3.

Oelke, L.M., R. Steiner, and P.W. Bosland. 2003. Differentiation of race specific resistance to phytophthora root rot and foliar blight in Capsicum annuum. J. Amer. Soc. Hort. Sci. 128:213-218.

Parra, G. and J.B. Ristaino. 2001. Resistant to mefenoxam and metalaxyl among field isolates of Phytophthora capsici causing phytophthora foliar blight of bell pepper. Plant Dis. 85:10691075.

Polach, F.J. and R.K. Webster. 1972. Identification of strains and inheritance of pathogenicity in $P$. capsici. Phytopathology 62:2026.

Poswal, M.A.T. 1988. Races of Xanthomonas campestris pv. malvacearum (Smith) Dye, the causal organism of bacterial blight of cotton in Nigeria. J. Phytopathol. 123:6-11.

Simon, M.R., F.M. Ayala, C.A. Cordo, M.S. Roder, and A. Borner. 2004. Molecular mapping of quantitative trait loci determining resistance to septoria tritici blotch caused by Mycophaerella graminicola in wheat. Euphytica 138:41-48. 
Skaggs, R., M. Decker, and D. VanLeeuwen. 2000. A survey of southern New Mexico chile producers: Productions, practices and problems. New Mexico Agr. Expt. Sta. Tech. Bul. No. 782.

Stakman, E.C. 1919. New biologic forms Puccinia graminis. J. Agr. Res. 16:103-105.

Sy, O., R. Steiner, and P.W. Bosland. 2005. Inheritance of phytophthora stem blight resistance as compared to phytophthora root rot and phytophthora foliar blight resistance in Capsicum annuum L. J. Amer. Soc. Hort. Sci. 130:75-78.

Sy, O., R. Steiner, and P.W. Bosland. 2008. Recombinant inbred line differential identifies race-specific resistance to phytophthora root rot in Capsicum annuum. Phytopathology 98:867-870.

van Poppel, P.M.J.A., D.J. Huigen, and F. Govers. 2009. Differential recognition of Phytophthora infestans races in potato $R 4$ breeding lines. Phytopathology 99:1150-1155. 